\title{
Chronic Venous Insufficiency (CVI) with Ulcus Cruris
}

\author{
M. Augustin \\ Department of Dermatology, University of Freiburg
}

\section{Definition}

Chronic venous insufficiency (CVI) denotes the stages of chronic venous weakness in the lower extremities. According to Widmer, the following stages are defined, which can be passed through in the course of years, particularly if left untreated: I - corona phlebectatica, ankle edema; II - trophic skin lesions, dermatitis, hyperpigmentation, dermatoliposclerosis; IIIa - healed ulcus cruris venosum; IIIb open ulcus cruris venosum. A new classification (CEAP Classification) reflects differentiated clinical, etiological, anatomical and pathophysiological characteristics of CVI. Because of its prevalence (ca. $12-15 \%$ of the population) CVI is of great socio-economic importance [Schultz-Ehrenburg et al., 1989; Marshall, 1989; Bartolo, 1992; Uber and Graf von der Schulenburg, 1995; Franks et al., 1995; Fowkes, 1996].

\section{Dermatological Diagnostics}

Required: The following examinations are routinely performed in venous complaints: Anamnesis, clinical status (inspection, palpation), Doppler examination, digital photoplethysmography (DPPG or LRR), duplex sonography where indicated.

Optional: The following should be considered in suspect findings: Phlebography, D-dimer Test (suspected thrombosis).

\section{Psychosomatic Diagnostics}

Levels of evidence (L1-L4)

Evidence is based on at least:

L1 = one randomized controlled clinical or experimental study or one systematic review,

L2 = one non-randomized, but controlled study,

L3 = more than one non-experimental study of high methodological value, L4 = expert opinion.

\section{Emotional Factors in Onset and Course (L3)}

Emotional factors which elicit or potentiate CVI have hardly been examined to date. However, Franks et al. [1995] found a relationship between socio-demographic variables and the healing tendency of ulcus cruris. Moreover, it can be assumed that emotional factors affect the patient's compliance [Augustin, 1997]. This, in turn, is important for the course of CVI - especially of higher stages [Kiev et al., 1990; Weidinger, 1993; Erickson et al., 1995; Tonge, 1995].

\section{Emotional Problems in Coping}

During CVI, there may be pronounced psychosocial stress [Dieterle et al., 1996]. This applies also for early stages of CVI [Launois, 1994; Garratt et al., 1993; Franks et al., 1994]. There are also increasing economic problems, especially in ulcus cruris - depending also on the health system involved [Lindholm et al., 1993; Philips et al., 1994].

In addition to the effects of age and sex (greater stress for elderly and in women) the limitations of quality of life depend on the stage of CVI [Augustin et al., 1997; Zschocke et al., 2002].

The role of ulcus cruris as a 'social ulcer", which guarantees attention, care and social contacts, has been emphasized by several authors [Wise, 1986; Flett et al., 1994]. The secondary benefits of the illness can thus be considerable, but this has not yet been systematically studied.

\section{Diagnostic Measures}

Required: It has been pointed out in several studies that symptoms of CVI may be imitated by somatoforme disorders [Kuny and Blättler, 1988; Blättler et al., 1992; Blättler and Davatz, 1993]. Among these are heavy and tired legs, dysesthesias, nocturnal cramps and sensations of burning which have to be particularly considered in the diagnostic process.

Optional: Psychometric inventories (e.g. State Trait Anxiety Inventory, STAI; Symptom Checklist, SCL-90, or Hospital Anxiety and Depression Scale, HADS, with respect to psychological symptoms; Marburger-Haut-Fragebogen, MHF, with respect to disease-specific overcoming; Freiburger Fragebogen zur Krankheitsverarbeitung, FKV, for coping). The question of secondary benefit of disease should be given special attention if the patient's compliance is obviously poor.

\begin{tabular}{ll}
\hline KARGER & ○ 2002 S. Karger GmbH, Freiburg \\
$\begin{array}{l}\text { Fax +49 7614520714 } \\
\begin{array}{l}\text { E-mail Information@Karger.de } \\
\text { www.karger.com }\end{array}\end{array}$ & Accessible online at: \\
www.karger.com/journals/dps
\end{tabular}

PD Dr. Matthias Augustin

Universitäts-Hautklinik

Hauptstraße 7

D-79104 Freiburg (Germany)

Tel. +49 $761270-6795$

E-mail augustin@haut.ukl.uni-freiburg.de 
With respect to quality of life the following inventories may be useful: Generic questionnaires e.g. Nottingham Health Profile (NHP), SF-36 Health Survey or EuroQoL, and disease-specific questionnaires, e.g. Freiburg Life Quality Assessment (FLQA) [Augustin et al., 1997].

\section{Therapy}

\section{Dermatological Therapy (L 1-4)}

External: The most important measures in CVI are compression therapy (L1), weight reduction where indicated, and mobility or physiotherapy (L2). In the case of refluxes in superficial or perforating veins, phlebectomy, sclerotherapy or ligation of perforating veins are performed (L2). Ulcera crurum are treated according to rules for treating chronic wounds. Systematic reviews are available for the following treatments: Compression for acute treatment and for preventing relapses, debridement, therapeutic ultrasound, electromagnetic therapy, intermittent pneumatic compression, laser therapy, wound dressings, topical negative pressure, skin grafting and pain therapy. Compression therapy, pain therapy and treatment of underlying causes are particularly important.

Internal: In addition to external venous therapies, venous pharmaceuticals, to which venous toning and edema-protective effects are ascribed, are broadly used (L1).

Psychosocial: Depending on the stress symptoms, supportive psychological interventions or social services may be indicated.

\section{Psychosomatic Therapy}

Psychosomatic Primary Care (L4)

Strengthening of a therapeutic relationship, expansion of the causal disease model, clarification of psychosocial effects of the disease and disease-specific stress, conflict-orientated interviews.

\section{Indications for Psychotherapy/Psychopharmacology Relaxation (L4) \\ Deep-Psychological and Analytical Procedures (L4)}

No controlled studies. Application according to general indication criteria for these procedures.

\section{Behavior Therapy (L4)}

No controlled studies. Application rarely indicated.

Hypnosis (L4)

No controlled studies. Application rarely indicated.

Psychopharmacology (L4)

Possibly psychopharmacological adjuvant treatment in severe ulcer pain.

\section{Training Programs and Combination Therapies (L4)}

No controlled studies. An uncontrolled study by Ruane-Morris et al. [1995] indicates benefits of healed leg ulcer groups with respect to prevention of recurrence. In analogy to studies in other dermatoses (see atopic dermatitis), training may be beneficial for better compliance and for learning of preventive behavior.

Self-Help (L4)

No specific self-help groups known. Occasionally, 'vein groups' are offered in some clinics, even for outpatients.

\section{References}

Augustin M, Zschocke I, Dieterle W, Vanscheidt W: Psychische Probleme und mangelnde Compliance bei Patienten mit CVI. Hautarzt 1997;48(S1)

Augustin M, Dieterle W, Zschocke I, Brill C, Trefzer D, Peschen M, Schöpf E, Vanscheidt W: Development and validation of a disease-specific questionnaire on the quality of life of patients with chronic venous insufficiency. VASA 26;1997:291-301.

Bartolo M: Impact socio-economique des maladies veinuses en Italie. Phlebologie 1992;45:423-431.

Blättler W, Davatz U: Zur Psychogenese vermeintlich venös bedingter Beinbeschwerden. Phlebologie 1993;22:57-60.

Blättler W, Freitag U, Künzli M, Frick E: Eine kleine psychometrische Untersuchung bei Patientinnen mit Ulcera cruris. Phlebologie 1992;21:16-19.

Dieterle W, Zschocke I, Vanscheidt W, Augustin M: Psychosoziale Belastungsfaktoren bei Patienten mit chronischer Veneninsuffizienz verschiedener Stadien; in Brähler E, Schumacher J (Hrsg): Psychologie und Soziologie in der Medizin. Gießen, Psychosozial Verlag, 1996, S. 33-34.

Erickson CA, Lanza DJ, Karp DL, Edwards JW, Seabrook GR, Cambria RA, Freischlag JA, Towne JB: Healing of venous ulcer in an ambulatory care program: The roles of chronic venous insufficiency and patient compliance. J Vascular Surg 1995;22: 629-636.

Flett R, Harcourt B, Alpass F: Psychosocial aspects of chronic lower leg ulceration in the elderly. West $\mathbf{J}$ Nurs Res 1994;16:183-192.
Fowkes FGR: Epidemiology of Chronic Venous Insufficiency. Phlebology 1996;11:2-5.

Franks PJ: Generic tools. J Wound Care 1996;5:143144.

Franks PJ, Bosnaquet N, Connolly M: Venous ulcer healing: effect of socioeconomic factors in London. J Epidemiol Community Health 1995;49:385-388.

Franks PJ, Moffatt PJ, Connolly M: Community Leg Ulcer Clinics: Effect on Quality of Life. Phlebologie 1994,9:83-86.

Franks PJ, Oldroyd MI, Dickson D, Sharp EJ, Moffatt $\mathrm{CJ}$ : Risk factors for leg ulcer recurrence: A randomized trial of two types of compression stocking. Age Ageing 1995;24:490-494.

Garratt AM, Macdonald LM, Ruta DA, Russell IT, Buckingham JK, Krukowski ZH: Towards measurement of outcome for patients with varicose veins. Oual Health Care 1993;2:5-10.

Kiev J, Noyes LD, Rice JC, Kerstein MD: Patient compliance with fitted compression hosiery monitored by photoplethysmography. Arch Phys Med Reha 1990;71:376-379.

Kuny S, Blättler W: Psychische Befunde bei vermeintlich phlebologischen Beinbeschwerden. Schweiz Med Wochenschr 1998;118:18-22.

Launois R: At the crossroads of venous insufficiency and hemorrhoidal disease: Daflon 500mg - repercussions of venous insufficiency on everyday life. Angiology 1994;45:495-504.

Lindholm C, Bjellerup M, Christensen OB, Zederfeldt B: Quality of life in chronic leg ulcer patients. An assessment according to the Nottingham Health Profile. Acta Derm Venereol 1993;73:440-443.
Marshall M: Sozialmedizinische Bedeutung, Kosten, Verlauf, Therapie und Prognose der Venenerkrankung. Versicherungsmedizin 1989;3:89-97.

Phillips T, Stanton B, Provan A, Lew R: A study of the impact of leg ulcers on quality of life: Financial, social, and psychologic implications. J Am Acad Dermatol 1994:31:49-53.

Ruane-Morris M, Thompson G, Lawton S: Supporting patients with healed leg ulcers. J Prof Nurs 1995 10:765-770.

Schultz-Ehrenburg U, Weindorf N, Von Usslar D: Prospektive epidemiologische Studie über die Entstehung von Krampfadern bei Kindern und Jugendlichen. Bochumer Studie I und II. Phlebol Proktol 1989;18:3-11.

Tonge H: A review of factors affecting compliance in patients with leg ulcers. J Wound Care 1995;4:84-

Uber A, Graf von der Schulenburg J: Sozio-ökonomische Aspekte der Veneninsuffizienz. Z Gesundheitswiss 1995;3:252-263.

Weidinger P: Compliance bei Kompressionsstrümpfen; in Gerlach HE (Hrsg): Training bei Venenerkrankungen. TM-Verlag, 1993.

Wise G: Overcoming loneliness. Nurs Times 1986; $37-42$.

Zschocke I, Bross F, Vanscheidt W, Augustin M: Quality of life in different stages of chronic venous insufficiency and leg ulcer. Dermatol Psychosom 2002;3:126-131. 